\title{
Entero-Hepatic Pathobiology: Histopathology and Semi-Quantitative Bacteriology of the Duodenum
}

- Author(s)

Ito NMK ${ }^{1,2}$

Miyaji $\mathrm{Cl}^{1,2}$

Lima $\mathrm{EA}^{2}$

Okabayashi $\mathrm{S}^{2}$

Claure RA ${ }^{3}$

Graça $\mathrm{EO}^{3}$

1 Universidade Santo Amaro-UNISA.

2 SPAVE Laboratório.

${ }^{3}$ Elanco Saúde Animal.

Mail Address

Rudy Anaya Claure

Eli Lilly do Brasil Ltda.

Divisão Elanco Saúde Animal

Avenida Morumbi, 8264

04.703-002 - São Paulo, SP, Brazil

Phone: +55 +11 5532-6858/5532-6735/ $5532-6911$

E-mail: claure_rudy_araya@lilly.com

Keywords

Broilers, enteritis, gut bacteriology, hepatitis.

acknowledgements

To poultry farmers and industries that allowed access to the samples.

\section{ABSTRACT}

Duodenum swabs were harvested from 80 broilers in 15 flocks of 8 broiler farms and were submitted to bacteriological evaluation. Five broiler breeders were sampled to obtain comparative data. Macro and microscopic lesions in the gut and the liver were evaluated in all birds submitted to swab harvesting and also broilers of two slaughter plants. Semiquantitative bacterial examination in duodenum swabs demonstrated higher microorganism growth in blood agar than in MacConkey medium. Staphylococcus sp, Enterococcus sp and Escherichia coli were found in some broiler flocks. An increased cellularity of the muscular mucosae of duodenum villi and/or the presence of some gametocytes or schizonts of coccidia were found in the lesioned gut in addition to high bacterial growth in blood agar. In some flocks, enlarged yellowish livers with vacuolated hepatocytes and/or increased reticuloendothelial response were seen in some birds. Liver and gut samples were collected in two slaughter plants in order to establish a pattern of response in broilers after withdrawal of growth promoters. Livers with macroscopic lesions presented microscopic lesions in the parenchyma such as increased leukocyte response in the sinusoidal space, vacuolar degeneration of hepatocytes or focal necrosis in the perilobular region, increased size or number of lymphoid nests in the perilobular region, the perivascular space and surrounding the biliary duct and increased extramedular granulocytopoiesis. Duodenum with hyperemic patches showed increased cellular response in the muscular mucosa of villi. These observations support the concept that semi-quantitative bacteriology and liver lesion evaluation could be used as a model to study gut bacterial imbalance in chickens.

\section{INTRODUCTION}

The intestine of broiler chickens is colonized by billions of more than 200 distinct species of bacteria (Mead, 1989). In the environment of hatchery and chicken houses, the intestine of day-old chicks is immediately colonized by many species of Gram negative and positive bacteria, aerobes (Mead \& Adams, 1975; Smith, 1965) and anaerobes (Karpinska et al., 2001). Different species of environmental bacteria enter the digestive system of day-old chicks through the ingestion of hatching dejects, food and water, and colonize distinct regions of the intestine at different rates of multiplication. Not all ingested bacteria adapt to the chicken gastrointestinal microenvironment and are thus eliminated in the feces, while others are destroyed by the immune system. Gut-colonizing bacteria generally have a commensal relationship with the host and are considered part of the normal intestinal flora. Although under some conditions bacteria of the normal flora may become noxious to the host, it is also well established that intestinal flora can improve growth performance of 
broilers or interfere with growth of pathogenic bacteria (Jin et al., 1998; Anderson, 2002). Bacteria from normal flora are commonly seen adhered to the mucous or in the gut epithelial cells (Füller, 1979).

The bacterial composition and concentration of normal flora in the different parts of the intestines changes during broiler rearing (Barnes et al., 1972). Anaerobic and aerobic Gram negative and positive bacteria are found in the ceca throughout the life of broilers. Conversely, poor bacterial colonization is found in the duodenum where anaerobic bacteria are not described as a part of normal flora. Gram positive aerobic microorganisms such as Lactobacillus $\left(10^{8}\right.$ to $10^{9} \mathrm{CFU} / \mathrm{g}$ ) and Streptococci ( $\leq 10^{2}$ to $\left.10^{4} \mathrm{CFU} / \mathrm{g}\right)$ predominate in the duodenum, while Gram negative bacteria like coliforms are absent or present in very low numbers (Barnes et al., 1997; Mead \& Adams, 1975). Duodenum microbiota can be altered during rearing due to some factors related to loss of natural defenses or stress or the use of antibiotics or growth promoters. An opportunistic bacterial infection or growth in the duodenum can be characterized by an increased number of bacteria or the appearance of bacterial species that are not naturally present in that region. Changes in duodenal microbiota are able to break the balance of natural commensalism and the beneficial effect of normal flora. Perhaps Moskalek et al. 1980, were the first to use the term dysbacteriosis to name the imbalance of normal bacterial flora as it has been used by Panneman (2000) in the last years. Duodenum semi-quantitative bacteriology evaluation can be performed in swabs taken from the lumen in order to detect dysbacteriosis (Panneman \& Van der Stroom-Kruyswijk, 2002). This paper describes the results of semi-quantitative bacterial growth in duodenum swabs and the biochemical identification of some of the main isolates. Histopathology of duodenum was also done in order to look for a relationship between isolated bacteria and host response. Mucosa damage in the intestine can be elicited by bacterial adherence and penetration in the epithelial cells or by absorbed bacterial toxins. Tissue injury and damage of epithelial layer of the gut can be caused by expression of simbiotic pathogenicity elicited by the presence of two species of environmental bacteria (e.g. Staphylococcus sp plus Streptococcus $s p$ ) or by the presence of pathogenic bacteria (Salmonella sp, Serpulina sp), which are able to attach and invade epithelial cells or the villous lamina propria. Unlike pathogenic bacteria, microorganisms from the normal intestinal flora are usually found as extracellular parasites that colonize the gut lumen. Infiltration of inflammatory cells and lymphoid hyperplasia may also be seen in the intestinal villi due to first colonization of bacteria from the normal flora and cause a decrease of nutrient absorption or competition for essential nutrients (Anderson et al., 1999; Leeson \& Summers, 2001).

Overgrowth of microorganisms of the normal flora can also be associated with release of toxic substances or an enhancement in nutrient degradation, such as aminoacids which originate vasoactive biogenic amines (e.g. histidin decomposition generates histamin, and lysin generates cadaverin) that can trigger inflammation and increased intestinal peristaltism. Bacterial toxins released in the crop or in the duodenum are absorbed in a greater magnitude than those released in the ceca (Larbier \& Leclerc, 1994). According to Guyton (1973), intestinal capillaries can absorb and transport bacteria and toxins to the liver. In normal conditions, intestine toxins and bacteria enter the liver through the portal system and are cleared by Kupffer cells. However, an overgrowth of gut microorganisms can induce an increased reticuloendothelial response in the hepatic sinusoids as well as induce hepatocyte injury. Intestinal E.coli, Klebsiella sp, Enterobacter sp, Staphylococcus sp and Clostridium sp, among others, can also reach the liver by the extrahepatic biliary duct and elicit cholangiohepatitis (Kaldhusdal \& Lovland, 1995), cholangitis and peri-cholangitis (Cotran et al., 1989). The incidence of injured livers in a broiler slaughter plant may help to estimate the occurrence of necrotic enteritis during the rearing period (Lovland \& Kaldhusdal, 2001). Based on the evidence of correlation between intestinal biota, enteritis and the occurrence of hepatic injury, histologic evaluation of livers was also performed.

\section{MATERIAL AND METHODS}

\section{Farms}

Six broiler farms using growth promoters against Gram positive and negative bacteria and anticoccidial drugs (Farms A, B, C, D, E) were included in the tests. One flock of adult broiler breeders (Farm $\mathrm{F}$ ) fed a ration with growth promoter against Gram positive bacteria and five broiler chickens flocks reared without anticoccidials and growth promoters were also evaluated.

\section{Duodenum sampling}

Five chickens randomly taken from each poultry house were submitted to individual sampling of duodenal swabs. Samplings were performed far from the housing plant and protected from drafts of air. 
Broiler breeders were sent to SPAVE Laboratory and submitted to swab sampling. Birds were sacrificed by cervical dislocation and the abdominal cavity was exposed according to Van Saene \& Van der Stroom's procedures (personal communication). The duodenal loop was removed manually from the carcass and a 3$\mathrm{cm}$ incision was made with a disposable sterile scalpel $1 \mathrm{~cm}$ away from the pylorus. Disposable swabs (Rexam) were used to sample contents and the superficial mucosa from opened duodenal loops and immediately smeared onto Petri dishes with medium. The unopened portion of the duodenum and livers presenting color alterations were fixed in 10\% formalin for further histopathological analysis.

\section{Semi-quantitative bacteriology}

Duodenal swabs were semi-quantitatively cultured according to Panneman \& Van der Stroom-Kruyswijk (2002). Petri dishes with MacConkey agar (Merck code 105465) or tryptone soya agar (Oxoid code CM131) with $5 \%$ of sheep red blood cells or SPS agar (Difco code 0845) were inoculated using the four quadrant method. The first quadrant was heavily streaked with the duodenal swab and a new sterile disposable swab was used to perform serial smearing to other quadrants. Smeared MacConkey agar and blood agar were incubated at $37^{\circ} \mathrm{C}$ for 18 to 24 hours in aerobic environment. Plates with SPS agar were kept in anaerobic jars for incubation. Bacterial growth was examined after incubation and scores from one to four were given according to the presence of colonies, respectively in the first, second, third and fourth quadrants of the Petri dish. Growth scores were given independent of the number of colonies found in each quadrant. After scoring, some predominant types of colonies were selected for further biochemical evaluation by BBL the crystal identification system.

\section{Histopathology}

Formalin fixed tissues were included in paraffin, sectioned and stained with haematoxylin-eosin.

\section{Liver lesions at slaughter}

Preliminary data were obtained during one day of slaughter in two broiler slaughter plants. These data were used in correlation studies between liver and duodenum microscopic lesions. Liver samples with three types of macroscopic lesions (pale, green and multifocal lesions) were fixed in 10\% formalin. Duodenums showing visible reddened areas in the muscular wall were also taken for histopathological analysis.

\section{RESULTS}

\section{Bacteriology}

Duodenum swabs taken from chickens fed with growth promoters showed low bacterial growth (score 1) or absence of growth when cultivated on MacConkey agar (Table 1). High bacterial growth ( $\geq 3.0$ ) was found when the swabs were smeared onto blood agar. All examined chickens $(100 \%)$ in five out of eleven evaluated flocks had high scores of bacterial growth. Broiler chickens fed rations without growth promoters (Table 2) presented a similar pattern of bacterial growth in agar blood media between 23 to 36 days of age. Bacteriological tests in SPS agar were not performed in farms $A, B$ and $C$. No bacterial growth was detected in SPS agar smeared with duodenum swabs from farms $D$ and $\mathrm{E}$ and in broiler flocks without growth promoters. Growth of Staphylococcus sp (distinct from S. aureus) was a common finding in duodenum swabs cultivated on blood agar from broilers fed or not with growth promoters. Enterococcus avium was found in farm A and Streptococcus sp in farm E (Table 1). Biochemically unidentified Gram positive and negative bacilli were found in the broiler from flock G3 (Table 2). Bacterial growth in MacConkey agar was related to $E$. colifflocks A2, B3 and E). Colonies of Hafnia sp or Koserella sp were found in flock $E$.

\section{Histopathology}

Microscopic analysis were performed in formalinfixed samples of duodenum taken from B3, B4, C7 and E10 flocks (Table 1) and G1, G2, G4 and G5 (Table 2). Low numbers of coccidial schizonts and gametocytes were found in some gut villi, except in duodenum samples taken from $\mathrm{G} 1$ and $\mathrm{G} 5$ flocks. Increased cellularity in the muscular mucosa of some villi (Figure 1) were found in seven flocks which presented bacterial overgrowth in agar blood media (score 3 to 4). G5 duodenum samples had no microscopic lesions in the muscular mucosa. Increased epithelial cell desquamation and mononuclear cell and heterophil exsudation were common findings. Epithelial necrosis in the Lieberkhün crypts were found in $\mathrm{G} 1$ samples. Yellowish livers were found in some birds with microscopically altered duodenum. Vacuolated hepatocytes were found by histopathological evaluation in such liver samples.

\section{Liver and duodenum samples from slaughter plant}

The presence of microscopic alterations was evaluated in seventeen liver samples obtained from 


\begin{tabular}{|c|c|c|c|c|c|c|}
\hline \multirow[t]{2}{*}{ Farm } & \multirow[t]{2}{*}{ Flock } & \multirow[t]{2}{*}{ Age (days) } & \multicolumn{2}{|c|}{ Scores of bacterial growth ${ }^{1}$} & \multicolumn{2}{|c|}{ Biochemical identification } \\
\hline & & & MacConkey agar & Blood agar & MacConkey agar & Blood agar \\
\hline A & 1 & 21 & $0,0,0,0,1$ & $1,2,1,1,1$ & Not performed & E.coli \\
\hline 2 & 30 & $0,1,0,0,0$ & $4,1,4,1,1$ & & & $\begin{array}{c}\text { Enterococcus avium } \\
\text { Staphylococcus sp or Micrococcus sp } \\
\text { Enterococcus avium }\end{array}$ \\
\hline \multirow[t]{2}{*}{ B } & 3 & 35 & $1,1,1,0,1$ & $1,4,3,2,4$ & E. coli & Staphylococcus sp or Micrococcus sp \\
\hline & 4 & 40 & $0,0,0,0,0$ & $4,4,4,4,4$ & & $\begin{array}{c}\text { Proteus sp } \\
\text { Staphylococcus } s p \text { or Micrococcus } s p\end{array}$ \\
\hline \multirow[t]{3}{*}{ C } & 5 & 24 & $0,1,0,1,1$ & $1,2,1,1,1$ & Not performed & Not performed \\
\hline & 6 & 30 & $0,0,0,1,0$ & $2,4,3,1,4$ & Not performed & Not performed \\
\hline & 7 & 42 & $1,0,0,1,1$ & $4,4,4,4,1$ & Not performed & Not performed \\
\hline \multirow[t]{2}{*}{ D } & 8 & 30 & $3,1,1,1,1$ & $4,4,4,4,4$ & Not performed & Staphylococcus sp \\
\hline & 9 & 35 & $1,1,1,1,0$ & $1,1,1,1,1$ & Not performed & Not performed \\
\hline$E$ & 10 & 30 & $0,2,0,0,0$ & $4,4,4,4,3$ & $\begin{array}{c}\text { E. coli } \\
\text { Hafnia sp or Koserella sp }\end{array}$ & $\begin{array}{l}\text { Proteus sp } \\
\text { Streptococcus sp } \\
\text { Staphylococcus sp }\end{array}$ \\
\hline $\mathrm{F}$ & 11 & 50 (weeks) & $1,0,0,0,0$ & $4,4,4,4,4$ & Not performed & Not performed \\
\hline
\end{tabular}

Table 2 - Score of bacterial growth in duodenum swabs from broiler chickens vaccinated against coccidiosis and fed diets without growth promoters.

\begin{tabular}{|c|c|c|c|c|}
\hline \multirow[t]{2}{*}{ Flock } & \multirow{2}{*}{ Age (days) } & \multicolumn{2}{|c|}{ Scores of bacterial growth ${ }^{1}$} & \multirow{2}{*}{ Biochemical identification } \\
\hline & & MacConkey agar & Blood agar & \\
\hline G1 & 23 & $4,0,0,1,1^{(a)}$ & $4,4,4,4,4$ & Staphylococcus sp \\
\hline G2 & 25 & $1,1,1,1,1$ & $4,2,4,4,3$ & Staphylococcus sp \\
\hline G3 & 26 & $1,2,4,1,3$ & $4,4,4,4,4$ & $\begin{array}{l}\text { Gram } \oplus \text { and } 0 \text { bacillus } \\
\text { Staphylococcus sp }\end{array}$ \\
\hline G4 & 36 & $1,1,1,2,2$ & $4,2,4,4,4$ & Not performed \\
\hline G5 & 41 & $0,1,1,1,1$ & $1,2,1,1,1$ & Not performed \\
\hline
\end{tabular}

slaughter plant A that were macroscopically classified as pale or whitish (3/17), green (10/17) and with multifocal necrosis (4/17). From slaughter plant $B$, it was evaluated 24 liver samples classified as pale or yellowish (14/24) or with mild multifocal necrosis (7/ 24) and green (3/24). According to Table 3, mild hyperplasia of reticuloendothelial cells around the perivascular space $(12 / 13=92.3 \%)$ and heterophils in the sinusoids $(7 / 13=53.8 \%)$ were the main findings in green livers. Pale or whitish or yellowish livers presented vacuolated hepatocytes (Figure 3A) $(16 / 17=94.1 \%)$ and an increased number of Küpffer cell-like cells in the sinusoids (Figure 3B) $(12 / 17=70.5 \%)$. Multifocal necrotic-like livers sampled from slaughter plant A presented mild hepatic injury characterized by focal accumulation of heterophils $(3 / 4=75 \%)$. Focal hepatocellular necrosis associated with an intense granulocyte migration (Figure 4A) or focal accumulation of reticuloendothelial cells (Figure $4 B$ ) were seen in 5/7 $(71.42 \%)$ and $2 / 7(28.7 \%)$ liver samples from slaughter plant $\mathrm{B}$, respectively.

Five samples of duodenum with reddened focal areas were taken from slaughter plant $A$. Oocytes were seen in the epithelial layer (4/5) and mononuclear cells were found in the muscular mucosae. Duodenum collected from chickens with pale liver at slaughter plant B presented schizonts and oocytes (2/14). Besides, lymphoid hyperplasia was a common finding in the tissue adjacent to Lieberkühn crypts. Livers with green color were seen in birds that also presented thickened villi due to the presence of mononuclear cells and heterophils. Similar lesions were seen in the duodenum of birds with necrotic livers. In both plants, the frequency of lesioned liver was lower than $0.1 \%$. 


\begin{tabular}{|c|c|c|c|c|c|c|}
\hline \multirow[t]{3}{*}{ Microscopic findings } & \multicolumn{6}{|c|}{ Macroscopical findings at the slaughter plant } \\
\hline & \multicolumn{2}{|c|}{ Green } & \multicolumn{2}{|c|}{$\begin{array}{l}\text { Whitish or } \\
\text { yellowish }\end{array}$} & \multicolumn{2}{|c|}{ Focal necrosis } \\
\hline & A & B & $A$ & B & A & B \\
\hline Hepatocyte vacuolation & $3 / 10^{1}$ & $2 / 3$ & $3 / 3$ & $13 / 14$ & $3 / 4$ & $0 / 7$ \\
\hline Reticuloendothelial cells in the sinusoidal space & $3 / 10$ & $1 / 3$ & $1 / 3$ & $11 / 14$ & $0 / 4$ & $0 / 7$ \\
\hline Heterophils in the sinusoids & $6 / 10$ & $1 / 3$ & $1 / 3$ & $4 / 14$ & $3 / 4$ & $5 / 7$ \\
\hline Accumulation of reticuloendothelial or lymphoid cells in the periportal space & $10 / 10$ & $2 / 3$ & $1 / 3$ & $8 / 14$ & $1 / 4$ & $2 / 7$ \\
\hline Myelocytes in the perivascular space & $2 / 10$ & $2 / 3$ & $0 / 3$ & $7 / 14$ & $0 / 4$ & $2 / 7$ \\
\hline Biliary pigment in the phagocytes & $0 / 10$ & $2 / 3$ & $0 / 3$ & $0 / 14$ & $0 / 4$ & $2 / 7$ \\
\hline Perilobular ischaemic necrosis & $0 / 10$ & $0 / 3$ & $0 / 3$ & $3 / 14$ & $0 / 4$ & $0 / 7$ \\
\hline Hepatocellular necrosis and focal Reticuloendothelial cell accumulation & $0 / 10$ & $0 / 3$ & $0 / 3$ & $10 / 14$ & $0 / 4$ & $5 / 7$ \\
\hline
\end{tabular}

1 - number of altered livers / total examined.

\section{DISCUSSION}

Coliform growth was not common in chickens fed growth promoters, according to the results of bacteriological semi-quantitative cultures of duodenum swabs in MacConkey agar. Growth scores $\geq 2.0$ were found in few birds fed with growth promoters $(2 / 55=$ $3.76 \%$ ) (Table 1). A slight increase in the frequency of individual scores for coliform growth was found in chickens without drugs (Table 6). According to Lee et al. (2002), based on PCR studies, broiler chickens fed with or without growth promoters did not present enterobacteria in the ileum after two weeks of age. The frequency of $E$. coli isolation in fourteen-day-old chicks is not high (Salanitro et al., 1978) and coliform isolation is supposed to be less than $10^{2} \mathrm{CFU} / \mathrm{g}$ of duodenum contents (Barnes et al., 1972). Chickens seem to have a normal low level of carriage state for environmental enterobacteria or coliforms in the duodenum, lesser than it is seen in human oropharynx. Overgrowth of aerobic Gram negative bacteria such as coliforms in human oropharynx was defined as higher than $10^{5} \mathrm{CFU} / \mathrm{mL}$ or a growth score of two or more (Stoutenbeek et al., 1984; Van Saene et al., 1999). Based on this approach, we can conclude that no flocks presented coliforms overgrowth. Mammals-like humans did not present Gram negative bacteria in the stomach and duodenum, so overgrowth can be defined as score one (Stoutenbeek et al., 1984; Van Saene et al., 1999). E. coli infection in mammals is most often a primary enteric disease, whereas in chickens colibacilosis is typically a secondary disease, either focal or systemic, that develops when host defenses have been impaired or overwhelmed. E.coli is a common inhabitant of the intestinal tract of poultry, mainly in the ceca, at concentrations up to 10\% $\mathrm{g}$ (Barnes et al., 1972; Barnes
\& Gross, 1997). Thus, it can be drawn that E. colifound in duodenum swabs was probably not causing the enteric alterations that were seen.

Aerobic Gram positive bacteria, mainly Lactobacillus and Streptococcus species, are found in the duodenum and ileum of healthy chickens (Barnes et al., 1972; Salanitro et al., 1978; Lee et al., 2002). In many broiler flocks, high aerobic bacteria growth (scores higher than one) were found when duodenum swabs were smeared onto blood agar (Tables 1 and 2). Staphylococcus $s p$ (or Micrococci), Streptococcus sp and Enterococcus sp were identified. According to Salanitro et al. (1978), Staphylococcus sp is not commonly found in the duodenum (less than $0.4 \%$ of frequency) or in the ileum (Lee et al., 2002). Enterococcus sp are found mainly in ileum and ceca (Mead, 1989; Lee et al., 2002). Enterococci, Streptococci and Staphylococci are Gram positive bacteria associated with a wide variety of diseases such as septicaemia, arthritis and dermatitis (Smith \& McNamee, 2001). Streptococcus faecium (Houghton et al., 1981) and Enterococcus hirae (Kondo et al., 1997) were reported to cause poor broiler performance, although its pathological role in the gut is not well known. The presence of such bacteria in the gut have no pathological significance. Gut overgrowth of Enterococci and coagulase-negative Staphylococci found in normal intestine flora was related to the occurrence of septicaemia in newborn stressed children (Pierrô et al., 1998). Overgrowth of bacteria in blood agar was defined as the presence $\geq 10^{5} \mathrm{CFU} / \mathrm{mL}$ microorganisms in the faeces and oropharynx samples of childrens (Pierrô et al., 1998), which would be equivalent to score $\geq 2.0$ found in the semi-quantitative bacteria culturing. Non-specific bacterial growth can occur in blood agar because this media is not selective and allow the growth of Gram negative and Gram 
positive bacteria, including Staphylococci, Streptococci and Pneumococci (Bier, 1990). Panneman \& Van der Stroom-Kruyswijk (2002) defined dysbacteriosis or Gram positive bacteria overgrowth in chickens when $25 \%$ or more than two birds from a total of five presented growth score one or when more than one quarter of smeared agar plate was positive for bacterial growth. The criteria of Panneman \& Van der Stroom-Kruyswijk (2002) for Gram positive bacteria overgrowth in the duodenum cannot be used to interpret our findings. Bacterial overgrowth in duodenum swabs smeared onto blood agar should be carefully interpreted, since $E$. coli and Proteus sp were found in some cultures in the present study (Table 1). Score $\geq 2.0$ could be defined as bacterial overgrowth in blood agar cultures of duodenum swabs of chickens. Otherwise, in case Staphylococcus sp or Enterococcus sp are found, even score one should be considered overgrowth or dysbacteriosis. Enterococci and Staphylococci are not members of the normal flora of the chicken duodenum (Lee et al., 2002). This hypothesis is reinforced by the fact that high scores of bacterial growth on blood agar were associated with gut villous damage and/or coccidia infection. It is well known that coccidia infection can be a starter factor for the imbalance in the bacterial community of the gut, eliciting wet litter, necrotic enteritis (Al-Sheikhly \& Al-Saieg, 1980; Ruff 1989; Gaskins \& Van der Klis, 2002; Hermans, 2002) and pathogenic bacterial growth (Baba et al., 1992). The gut damage seen in the studied broiler flocks cannot be related to subclinical necrotic enteritis, since Gram positive anaerobes like Clostridium sp were not isolated in SPS agar, as reported by Ficken \& Wages (1997). Results from Tables 1 and 2 suggest that broiler chickens fed with anticoccidial drugs and growth promoters have bacterial overgrowth in blood agar during growing and finishing periods. Coccidia-vaccinated broiler flocks not fed growth promoters presented high scores in the initial period of rearing. Further studies should be performed to confirm this preliminary finding.

Bacterial-induced tissue damage can be elicited by growth and invasiveness and/or toxin synthesis and release. Gram positive bacteria release mainly exotoxins during multiplication. Endotoxins (LPS-lipopolysaccharides) are released by Gram negative bacteria when the microorganisms die. Gut bacteria and toxins can be absorbed and transported by the vessels and enter through the portal route into the liver, where they are cleared by sinusoidal Küpffer cells (Guyton, 1973; Cotran et al., 1989). Bacterial overgrowth in the gut can induce hepatitis (Lichtman et al., 1990). According to the toxicity or pathogenicity of the microorganisms, translocation of gut bacteria or toxins to the liver causes an increased response of resident reticuloendothelial cells (Küpffer cells) and cell accumulation at the periportal space. Hepatocellular degeneration, central vein injury or extensive liver damage can be found when gut translocation is chronic (Cotran et al., 1989) or in anaerobic bacterial overgrowth (Lichtman et al., 1990). According to Lovland \& Kaldhusdal (2001), evaluation of liver lesions in the broiler slaughter plant might help to estimate clostridial enteritis during the rearing period. Clostridium perfringens-induced hepatitis is a cause of performance decrease in broilers (Kaldhusdal \& Hofshangen, 1992; Ficken \& Wages, 1997; Lovland \& Kaldhusdal, 2001; Kaldhusdal et al., 2001) and germfree birds (Fukata et al., 1988). It might cause predisposition for other diseases (Cullen et al., 1977) and occurrence of necrotic enterits (Al-Sheikhly \& Truskott, 1977; Kaldhusdall \& Hofshangen, 1992). Liver microscopic scoring was done in rats to establish the rate or nature of injury based on twelve parameters (Lichtman et al., 1990): (1) number of polymorphonuclear cells at the portal space; (2) and parenchyma; (3) biliary duct hyperplasia; (4) increased exsudation of inflammatory cells; (5) central vein inflammation; (6) number of lymphocytes at the portal space; (7) and parenchyma, (8) hepatocellular necrosis; (9) mononuclear cells or macrophages in the parenchyma; (10) or at the portal space; (11) vacuolar degeneration of hepatocytes and (12) number of altered portal space and central vein. A similar approach was used in this research to establish the relationship of macroscopic and microscopic liver damage. According to Figure $3 \mathrm{~A}$ and Table 3, yellowish or whitish livers were related with hepatocyte vacuolar degeneration and a variable frequency of other parameters. This kind of liver response could be related to toxigenic injury (Cotran et al., 1989). Focal or diffuse pinpoint or nodular lesions in the liver can be caused by gut bacterial translocation through the portal vein or biliary duct. Clostridium perfringens-like bacteria (Lovland \& Kaldhusdal, 2001), Salmonella sp and other bacteria (Calnek et al., 1997) might use this route and cause acute or chronic necrotic damage in the liver. Similar liver injury in humans can be elicited by Clostridium $s p$ and gut microorganisms like group D Streptococci (which include Enterococcus sp), Candida sp, antibiotic resistant bacteria (Staphylococci, Pseudomonas sp, Enterobacter sp) and anaerobes (Cotran et al., 1989). Some samples of liver taken at the slaughter plant (Table 3) presented acute-type lesions characterized by intense 
heterophil exsudation and focal necrosis (Figure 4A) or chronic-type injuries related to lymphoid cell response (Figure 4B) that could be elicited by bacterial invasion or toxigenic stimulus. Staphylococci bacteremia is generally associated with levels higher than $10^{5} \mathrm{CFU}$ in blood, lungs and liver of turkeys and liver necrosis associated with an increase of mononuclear cells and heterophils. Streptococcisystemic infections are related to hepatic necrosis associated with mild cellular reaction, although liver granulomas have been reported in turkeys. S. faecalis was reported to alter the intestine similarly to other Gram positive bacteria such as Bacteroides, Catenabacterium, Proprionibacterium, Corynebacterium, Streptococci, Staphylococci and Lactobacillus related to liver granuloma (Gross, 1997). Clostridium perfringens-associated hepatic lesions were related to an extensive proliferation of bile ductules and interlobular connective tissue fibrosis (Randal \& Reece, 1996; Sasaki et al., 2000) in the presence or absence of bacterial isolation. Clostridium is a typical example of gut bacterium that can induce toxigenic injury in the liver. Bacterial toxigenic injury in the liver may also be induced by overgrowth of gut bacteria and release of exotoxins and/or bacteria translocation to the liver and release of endotoxins after bacterial killing by reticuloendothelial cells.

The perivascular accumulation of myelocytes or immature granulocytes was seen mainly in yellowish or whitish livers (Table 3) (7/7). Acccording to Riddell (1987), the myelocyte response refers to extramedullar granulocytopoiesis. Extramedular granulocytopoiesis occurs in many tissues during chicken embryonic life and bone marrow is the primary site of cell differentiation after hatching. Nevertheless, extramedullar foci of myelocytes can be seen in the liver, spleen, kidney, thymus, nerves, gut, bursa of Fabricius, ovary, and other organs of adult birds (Riddel, 1987; Randall \& Reece, 1996). In these organs, diffuse or nodular foci up to $0.5 \mathrm{~cm}$ of diameter can be found. The foci contain erythrocytes, myelocytes and blasts that can be recognized as extramedullar granulocytopoiesis instead of myelocytomatosis. In the case of myelocytomas seen in myeloid leukosis, mitosis figures are found in myelocytes (Riddell 1987; Randall, 1991; Randall \& Reece, 1996). It is not known why an increased number of extramedullar granulocytopoiesis is found in some situations, in association with lymphoid cell hyperplasia. Thus, increased extramedular granulocytopoiesis could be related to an increase in heterophil response during any injury or infection in chickensand represents the increase of blood marginal pool of metamyelocytes. Our results support the concept that hepatic alterations could be related to duodenum injury due to Gram positive bacteria overgrowth. Nevertheless, further studies should be performed to elucidate the role of Staphylococci and Enterococcus $s p$ found in some flocks.

\section{CONCLUSION}

The results found in this research support the concept that semi quantitative bacteriology in selective medium and identification of the predominant bacterial and liver lesion could de used to make a presumptive diagnosis of gut flora imbalance or bacteria and toxin gut translocation.

\section{REFERENCES}

Al-Sheikhly F, Al-Saieg A. Role of coccidia in the occurrence of necrotic enteritis of chickens. Avian Diseases 1980; 24(2):324-333.

Al-Sheikhly F, Truskott RB. The pathology of necrotic enteritis of chickens following infusion of broth cultures of Clostridium perfringens into the duodenum. Avian Diseases 1977; 21:230-240.

Anderson BD, MacCraken VJ, Aminov RI, Simpson JM, Mackie RI, Vestergen MWA, Gaskins HR. Gut microbiology and growth promoting antibiotics in swine. Pig News and Information 1999; 20(4): $115 \mathrm{~N}-122 \mathrm{~N}$.

Anderson DB. Intestinal microbes: when does normality change into a health and performance insult? The Elanco Global Enteritidis Symposium, Cambridge UK 2002; p.3-17.

Baba E, Wakashima H, Fukui JK, Fukata T, Arakawa A. Adhesion of bacteria to the cecal mucosal surface of conventional and germfree chickens infected with Eimeria tenella. American Journal of Veterinary Research 1992; 53(20):194-7.

Barnes EM, Mead GC, Barnum DA. The intestinal flora of the chickens in the period 2 to 6 weeks of age, with particular reference to the anaerobic bacterias. British Poultry Science 1972; 13:311326.

Barnes HJ, Gross WB. Collibacilosis. In: Calnek BW, Barnes HJ, Beard CW, McDougald LR, Saif YM, editors. Diseases of Poultry. 10ed. Ames: Iowa State University Press; 1997. p. 131-141.

Bier O. Microbiologia e Imunologia. 30ed. São Paulo: Melhoramentos; 1990.

Calnek BW, Barnes HJ, Beard CW, McDougald LR, Saif YM, editors. Diseases of Poultry. Ames: lowa State University Press; 1997.

Cotran RS, Kumar V, Robbin SL. Robbin's Pathologic Basis of Disease. 4ed. Philadelphia: WB Saunders Company; 1989.

Cullen GA, Gordon RF, Harry EG, Jordan FTW. Bacterial Diseases. 
In: Gordon RF, editor. Poultry Diseases. 1ed. Bailliere Tindall; 1977. p. 58-64.

Ficken MD, Wages DP. Necrotic Enteritis. Clostridial Diseases. $\mathrm{n}$ : Calnek BW, Barnes HJ, Beard CW, McDougald LR, Saif YM, editors. Diseases of Poultry. 10ed. I Ames: lowa State University Press; 1997. p. 261-8.

Füller R. Bacterial attachment to the epithelium of the alimentary tract. ARC Research Review 1979; 5(2):31-4.

Fukata T, Hadate $\mathrm{Y}$, Baba E, Uemura T, Arakawa A. Influence of Clostridium perfringens and its toxin in germ-free chickens. Research of Veterinary Science 1988; 44 (1):68-70.

Gaskins HR, van der Klis DJ. Pathophysiology of clostridial enteritis and the impact of treatment: lessons from a chick model. The Elanco Global Enteritis Symposium, Cambridge, UK 2002; p. J1-J11.

Gross WB. Miscellaneous Bacterial Diseases. In: Hofstad MS, Barnes HJ, Calnek BW, Reid WM, Yoder Jr. HW, editors. Diseases of Poultry. 8ed. Ames: lowa State University Press; 1997. p 257-282.

Guyton AC. Tratado de Fisiologia Médica. 4ed. Rio de Janeiro: Guanabara Koogan; 1973.

Houghton SB, Fuller R, Coates ME. Correlation of growth depression of chicks with the presence of Streptococcus faecium in the gut. Journal of Applied Bacteriology 1981; 51(1):113-120.

Hermans P. The epidemiology of necrotic enteritis. The Elanco Global Enteritis Symposium Proceedings, Cambridge UK 2002; p. H1-H7.

Jin LZ, Ho YW, Abdulah N, Jalaludin S. Growth performance, intestinal microbial populations, and serum cholesterol broilers fed diets containing lactobacillus culture. Poultry Science 1998; 77(9):1259-1265.

Kaldhusdal M, Hofshangen M. Barley inclusion and avoparcin supplementation on broiler diets 2. Clinical, pathological and bacteriological findings in a mild form of necrotic enteritis. Poultry Science 1992; 71(7):1145-53.

Kaldhusdal M, Lovland A. Clostridium perfringens necrotizing enteritis of the fowl: a light microscopic, immuno-histochemical and ultrastructural study of spontaneous disease. Avian Pathology 1995; 24(3):421-433.

Kaldhusdal M, Schneits C, Hofshagen M, Skjerve E. Reduced incidence of Clostridium perfringens - associated lesions and improved performance in broilers chickens treated with normal intestinal bacteria from adult fowl. Avian Diseases 2001; 45:149156.

Karpinska E, Blaszczak B, Kosowska G, Degorki A, Binek M, Borzemska WB. Growth of the intestinal anaerobes in the newly hatched chicks according to the feeding and providing with normal gut flora. Bulletin Veterinary Institute Pulawy 2001; 45:105-9.

Kondo H, Abe N, Tsukuda K, Wada Y. Adherence of Enterococcus hirae to the duodenal epithelium of chicks with diarrhoea. Avian Pathology 1997; 26(1):189-194.
Larbier M, Leclercq B. Nutrition and feeding of poultry. Nothingham University Press, 1994.

Lee MD, Lu J, Idris U, Barman B, Hofacre C, Maurer JS. Microbial dynamics of the broiler intestinal tract. The Elanco Global Enteritis Symposium Proceedings, Cambridge UK 2002; p. A1-A14.

Leeson S, Summers JD. Non-nutritive feed additives. In: Scott's Nutrition of the Chicken. 4ed. Guelph: University Books; 2001. p. 429-455.

Lichtman SN, Sartor RB, Keku JB, Schwab JH. Hepatic inflammation in rats withexperimental small intestine bacterial overgrowth. Gastroenterology. 1990; 98:414-423.

Lovland A, Kaldhusdal M. Liver lesions seen at slaughter as the indicator of necrotic enteritis in broiler flocks. FEMs Immunology and Medical Microbiology 2001; 24:345-351

Mead GC, Adams BW. Some observation on the cecal microflora of the chick during the first two weeks of life. British Poultry Science 1975; 16:69-176.

Mead CG. Microbes of the avian cecum: types present and substrates utilized. Journal of Experimental Zoology 1989; 3:48-54.

Moskalek RS, Nikolaeva AM, Timoshko MA. Experimental dysbacteriosis in gnotobiotic chicks (changes in the intestinal flora produced by chloramphenicol or polimixin) Moscow: Veterinaya; 1979; 7:38-41 ibid Poultry Abstract 1980; 6(5)145.

Panneman H. Clostridial enteritidis/dysbacteriosis. Fast diagnosis by T-RFLP, a novel diagnostic tool. Elanco Poultry Enteritis Conference August 21st; 2000, Montreal, Canada. p. 21-9.

Panneman $H$, van der Stroom-Kruyswijk. Concept: Microbial Community Profiling and Characterization (MCPC). A comparison with other methods for the diagnosis of bacterial overgrowth in the duodenum of broiler chickens. The Elanco Global Enteritis Symposium Proceedings, Cambridge UK 2002; p. E1-E7.

Pierrô A, van Saene HFK, Jun AJ. Clinical impact of abnormal gut flora in infants receiving parenteral nutrition. Annals of Surgery 1998; 227(4):547-552.

Randall C. Diseases and disorders in the domestic fowl and turkey. 2ed. London: Mosby-Wolfe, 1991.

Randall CJ, Reece RL. Color Atlas of Avian Histopatology. 1ed. London: Mosby-Wolfe; 1996.

Riddell C. Avian Histopathology. 1ed. Lawrence: Allen Press Inc; 1987.

Ruff MD. Interaction of avian coccidiosis with other diseases: a review. Proceedings of the $\mathrm{V}^{\text {th }}$ International Coccidiosis Conference 1989; p.173-181.

Salanitro JP, Blake PA, Muirhead PA, Maglio M, Goodman JR. Bacteria isolated from the duodenum, ileum and cecum of young chicks. Applied and Envirommental Microbiology 1978; 35:782900. 
Sasaki J, Goryo M, Okoshi N, Furukawa H, Honda J, Okada K. Cholangiohepatitis in broiler chickens in Japan: histopathological, immunohistochemical and microbiological studies of spontaneous disease. Acta Veterinaya Hungarica 2000; 48(1):59-67.

Smith HW. The development of the flora of the alimentary tract in young animals. Journal Pathology Bacteriology 1965; 90:495-513.

Smith JA, MacNamee PT. Staphylococci, Streptococci and Enterococci. In: Jordan F, Pattison M, Alexander D, Faragher T, editors. Poultry Disease. 5ed. London: W. B. Saunders; 2001. p.1639.

Stoutenbeeck CP, van Saene HFK, Miranda DF, Zandstra DF. The effect of selective decontamination of digestive tract on colonization and infection rate in politraumatized patients. Intensive Care Medicine 1984; 10:185-192.

Van Saene HFK, Tometzki AP, Fairclough SJ, Rommes JH, Petros AJ. Carriage colonization and infection. In: Giar J, editor. Internal Care Medicine. BMJ Books; 1999. p.210-218. 


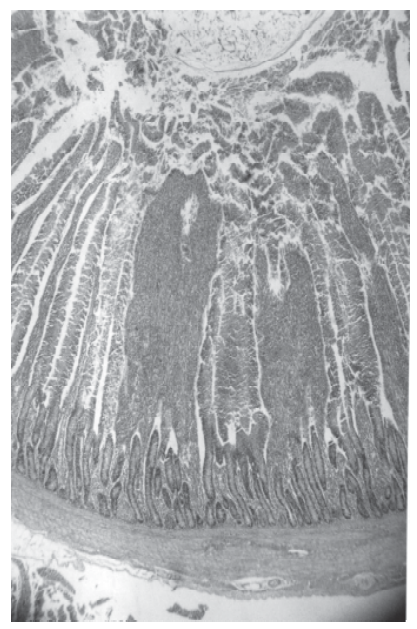

Figure 1 - Histologic section of duodenum stained with haematoxilin eosin dye (100x magnification). Thickned villous (arrows) with increased cellularity.

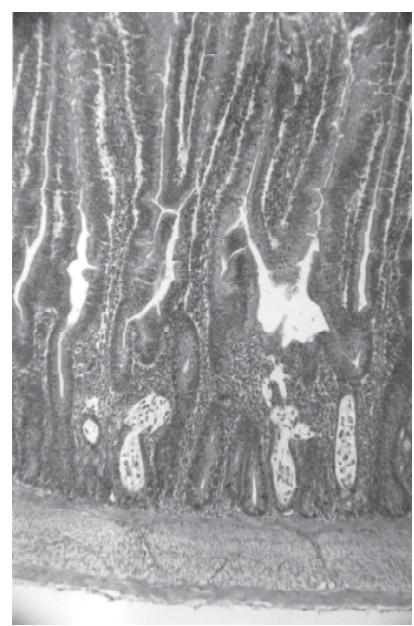

Figure $\mathbf{2}$ - Histologic section of duodenum stained with haematoxylin eosin dye (100x magnification). Epithelial necrosis is seen in the Lieberkhün cript (arrows).
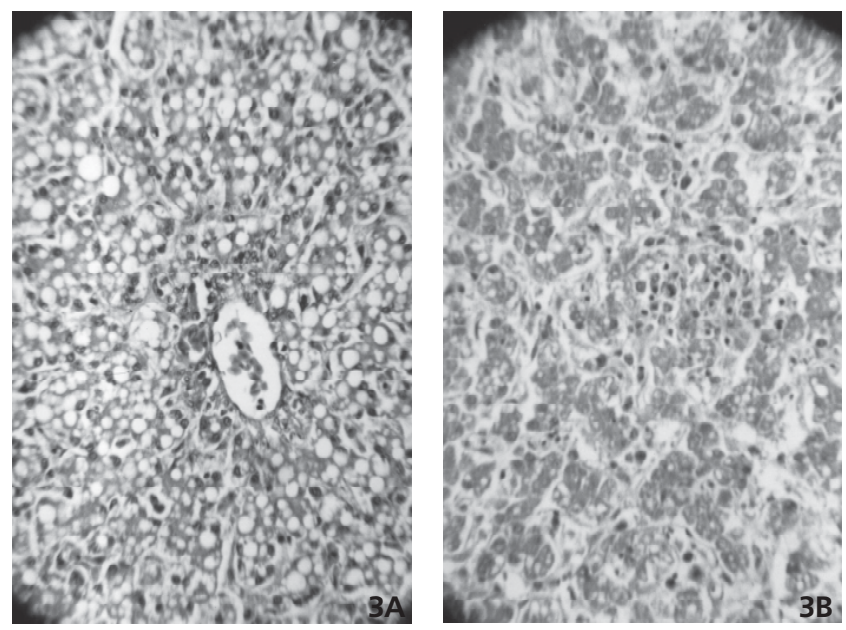

Figure $\mathbf{3}$ - Whitish or yellowish liver histologic section stained by haematoxylin eosin dye (400x magnification). Vacuolated hepatocytes is seen in the figure 3A. Shrunken vacuolated hepatocytes are surrounding by a distended sinusoids with plasmatic material and mononuclear cells (Figure 3B).
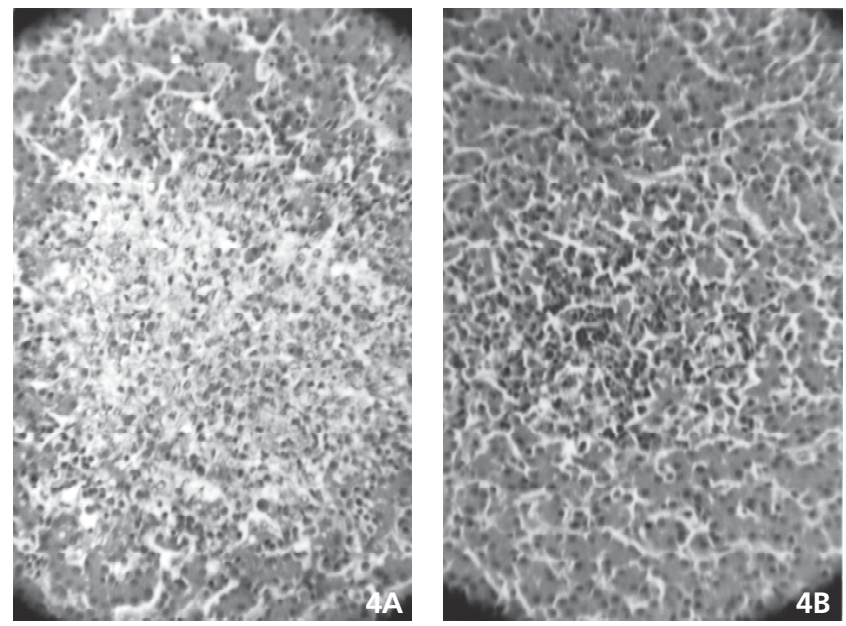

Figure 4 - Histologic section of liver with pinpointed or focal lesions stained by haematoxilin eosin dye (400x magnification). Focal necrosis with infiltration of heterophils is found in the figure 4A. Hepatocelular atrophy and massive accumulation of lymphoid and mononuclear cells is seen in the parenquima (Figure 4B) 